Research Article

\title{
Assessment of Knowledge and Attitude on Palliative Care among Student Nurses in Selected College of Nursing, New Delhi
}

\section{Sheeba Annie Chacko}

Tutor, Rufaida College of Nursing, School of Nursing Sciences and Allied Health, Jamia Hamdard (Deemed to be University), New Delhi, India.

DOI: https://doi.org/10.24321/2455.9318.202024

\section{I $\quad \mathbf{N} \quad \mathbf{F} \quad \mathbf{O}$}

E-mail Id:

sheebaanniechacko@gmail.com

Orcid Id:

https://orcid.org/0000-0003-3426-4752

How to cite this article:

Chacko SA. Assessment of Knowledge and Attitude on Palliative Care among Student Nurses in Selected College of Nursing, New Delhi. Int J Nurs Midwif Res 2020; 7(3): 36-41.

Date of Submission: 2020-11-18

Date of Acceptance: 2021-03-01

\section{$\begin{array}{llllllll}\mathbf{A} & \mathbf{B} & \mathbf{S} & \mathbf{T} & \mathbf{R} & \mathbf{A} & \mathbf{C} & \mathbf{T}\end{array}$}

Introduction: Palliative care is one of the most integral part of health care system which offers a support system to help the patients live peacefully until his last breath. Assessing the knowledge and attitude towards the palliative care can help us to understand the neglected area of concern and can enhance the student nurses to be competent while providing the care to the needy.

Objectives: The aim of the study were to assess the knowledge and attitude regarding palliative care among student nurses and to find the association between the knowledge and with their socio-demographic characteristics.

Materials and Methods: A quantitative research approach with descriptive survey design was selected for the study. The non-probability convenient sampling technique was used to select 100 student nurses (in the age group of 18-21 years and above 21 years) in selected college of nursing, New Delhi. A valid and reliable structured questionnaire to assess the knowledge and likert scale to assess the attitude among student nurses, were used to collect data in 1 week. A significant association was found between the knowledge score and with nursing course, area of residence and religion as selected sociodemographic variables. Maximum (54\%) of student nurses had inadequate knowledge score, but their attitude towards palliative care was (58\%) good. Due attention should be given towards palliative care by all the health care institutions and needs to be incorporated in the curriculum of nurse education.

Keywords: Knowledge, Attitude, Palliative Care, Student Nurses

\section{Introduction}

Palliative care has become an indispensable part of human life to provide effective care to the terminally ill patients so as to attain normal life and to provide peaceful death. It improves the quality of life of clients and their families facing the problem related to serious illness, by early identification, assessment and treatment of pain and other problems. ${ }^{1}$

Palliative Care, provides relief from the symptoms and 
stress for the people living with life-threatening illness by providing specialized medical care - whatever the diagnosis. The goal is to improve quality of life for both the patient and the family. ${ }^{2}$

Palliative Care is a human right for the people who are among the most vulnerable in society. ${ }^{3}$ At present scenario, the shift is observed from acute to chronic illness in India therefore around 6 million people in a year needs palliative care and the care at home has become a need and less than $3 \%$ cancer patient get access to adequate pain relief. ${ }^{4}$ In 2018 alone over 7,50,000 cancer deaths are observed, with Over one million new cases of cancer are registered in India every year.5 Palliative care at the end of life is required $80 \%$ approximately by all adults and children dying from cancer. Unnecessary hospitalizations and use of health-care services can be reduced by early palliative care. ${ }^{6}$

Today, patients with various diseases related to cancer, heart and lungs diseases, AIDS, amyotrophic lateral sclerosis, Alzheimer's, multiple sclerosis, etc. are eligible for palliative care. $^{7}$

All the states of India, need to think upon how to access the care and reach to patients who are in need of palliative care, starting from the initial day of diagnosis so as to provide quality life till their last breath and on the other hand providing psychological support to the patient's family who are in stage of grief and enable these family members to come out of their stress and participate in treatment activities.

Knowing the impact about how the health and care of critically or terminally ill patients are affected, requires a need for the student nurses to be aware about all the aspects of palliative care starting from the diagnosis of disease to provide prompt treatment.

\section{Statement of the Problem}

A descriptive study to assess the knowledge and attitude regarding palliative care among student nurses in selected College of Nursing, New Delhi.

\section{Objectives}

- To assess the knowledge regarding palliative care among student nurses

- To assess the attitude regarding palliative care among student nurses

- To find out the association between the knowledge and socio-demographic variables

\section{Materials and Methods}

A quantitative research approach with descriptive design was used for the study. The non-probability convenient sampling technique was used to select 100 student nurses (in the age group of $18-21$ years and above 21 years) in selected college of nursing, New Delhi.
An online informed consent was taken from each study subject. They were assured of anonymity and confidentiality of the information provided during the study. The data was collected in 1 weeks at selected College of Nursing.

The selected 100 student nurses were provided with online tool through Google forms which consisted of 2 Sections: where Section-1 consisted of demographic profile with 8 items on personal data such as age, gender, nursing course, area of residence, religion, previous knowledge, previous experience, and source of information and Section-2 consisted of 2 parts: In which Tool-1 consist of 30 multiple choice question to assess the Knowledge of Student Nurses regarding Palliative Care. Each correct answer was awarded a score of 1 mark and for each wrong answer 0 mark was awarded. Each question had four possible options of which one was correct and Tool-2 consisted of 20 questions to assess the Attitude of Student Nurses regarding Palliative Care. A self-designed questionnaire was developed to assess the attitudes toward palliative care. The instrument was scored on a five-point Likert scale ranging from 1 (strongly disagree) to 5 (strongly agree). 10 items were worded negatively and 10 worded positively. Thus, the scores of negative items were reversed.

Questions were related to definition, principles, terms, various aspects of palliative care such as physical, psychological, social, spiritual, cultural, care of dying, ethical and legal aspects of care.

The average time taken to answer the tool was 45-60 minutes. Data collected was organized, tabulated, analyzed and interpreted using descriptive and inferential statistics.

\section{Result}

\section{Demographic Variables}

Table I.Frequency and percentage distribution of student nurses by their demographic characteristics

$(n=100)$

\begin{tabular}{|c|c|c|}
\hline Demographic profile & $\begin{array}{c}\text { Frequency } \\
\text { (n) }\end{array}$ & $\begin{array}{c}\text { Percentage } \\
\text { (\%) }\end{array}$ \\
\hline \multicolumn{3}{|c|}{ Age (in years) } \\
\hline $18-19$ & 17 & $17 \%$ \\
\hline $20-21$ & 57 & $57 \%$ \\
\hline$>21$ & 26 & $26 \%$ \\
\hline \multicolumn{2}{|c|}{ Gender } \\
\hline Male & 19 & $19 \%$ \\
\hline Female & 81 & $81 \%$ \\
\hline DGNM 2 ${ }^{\text {nd }}$ year & 35 & $35 \%$ \\
\hline BSc. $3^{\text {rd }}$ year & 35 & $35 \%$ \\
\hline BSc. $4^{\text {th }}$ year & 30 & $30 \%$ \\
\hline
\end{tabular}




\begin{tabular}{|c|c|c|}
\hline \multicolumn{3}{|c|}{ Area of residence } \\
\hline Urban & 80 & $80 \%$ \\
\hline Rural & 20 & $20 \%$ \\
\hline \multicolumn{3}{|l|}{ Religion } \\
\hline Hindu & 34 & $34 \%$ \\
\hline Muslim & 57 & $57 \%$ \\
\hline Christian & 4 & $4 \%$ \\
\hline Others (Buddhism, Sikh) & $(3+2) 5$ & $5 \%$ \\
\hline \multicolumn{3}{|c|}{ Previous knowledge } \\
\hline Yes & 100 & $100 \%$ \\
\hline \multicolumn{3}{|c|}{ Previous experience } \\
\hline Yes & 33 & $33 \%$ \\
\hline No & 67 & $67 \%$ \\
\hline \multicolumn{3}{|c|}{ Source of information } \\
\hline Books & 27 & $27 \%$ \\
\hline Internet & 15 & $15 \%$ \\
\hline Friends and colleagues & 7 & $7 \%$ \\
\hline Teacher & 41 & $41 \%$ \\
\hline Hospital & 9 & $9 \%$ \\
\hline Training or conferences & 1 & $1 \%$ \\
\hline
\end{tabular}

of students nurses were females and 19\% were males; $35 \%$ of participant were from DGNM $2^{\text {nd }}$ years, followed by $35 \%$ from B.Sc. nursing (hons) 3rd year, and 30\% from B.Sc. nursing (hons) 4 th year students. Majority $80 \%$ population stayed in Urban area. More than half of (57\%) Student Nurses belonged to the Muslim community; $100 \%$ of student nurses were having previous knowledge regarding palliative care whereas $67 \%$ were not having previous experience and $33 \%$ were having previous experience related to palliative care; and $41 \%$ of student nurses got information's regarding palliative care from the teachers.

\section{Knowledge Assessment Scores}

Table 2, show knowledge score data reveals that out of 100 participants, the mean \pm standard deviation knowledge score obtained was $18.14 \pm 3.68$ and median was 22 . More than half (54\%) of the student nurses had inadequate knowledge score whereas $46(46 \%)$ of them had adequate knowledge score regarding palliative care.

\section{Attitude Assessment Scores}

Table 3, reveals that more than half of the student nurses agreed much more in the questions related to, (54\%) palliative care improves quality life of patient; (53\%) nurse should establish a supportive relationship with specialist; (51\%) work as a support system to help patients live as actively as possible until death; (53\%) willing to learn about the cultures of their patient and (52\%) respect the patients right to health in any condition.

Table 1, show the findings obtained from the study, revealed that out of 100 sample more than half (57\%) of the students nurses were in age group of 20 to 21 years; majority (81\%)

Table 2.Mean, median and standard deviation, percentage of obtained scores in terms of level of the student nurses

$(n=100)$

\begin{tabular}{|c|c|c|c|c|c|}
\hline \multirow{2}{*}{$\begin{array}{c}\text { Possible range } \\
\text { of knowledge } \\
\text { score }\end{array}$} & \multirow{2}{*}{$\begin{array}{c}\text { Obtained range } \\
\text { of knowledge } \\
\text { score }\end{array}$} & \multirow{2}{*}{$\begin{array}{c}\text { Mean } \pm \text { standard } \\
\text { deviation }\end{array}$} & \multirow[b]{2}{*}{ Median } & \multicolumn{2}{|c|}{ Percentage of obtained knowledge scores } \\
\hline & & & & $\begin{array}{c}\text { Inadequate } \\
\text { knowledge (0-18) }\end{array}$ & $\begin{array}{c}\text { Adequate } \\
\text { knowledge (19-30) }\end{array}$ \\
\hline $0-30$ & $05-25$ & $18.14 \pm 3.68$ & 22 & $54 \%$ & $46 \%$ \\
\hline
\end{tabular}

Table 3.Percentage distribution of Subjects in terms of their attitude regarding Palliative Care

$(n=100)$

\begin{tabular}{|c|c|c|c|c|c|c|}
\hline \multirow{2}{*}{$\begin{array}{l}\text { S. } \\
\text { No. }\end{array}$} & \multirow[t]{2}{*}{ Questions } & $\begin{array}{l}\text { Strongly } \\
\text { Disagree }\end{array}$ & Disagree & $\begin{array}{c}\text { Neutral } \\
\text { (Not Sure) }\end{array}$ & Agree & $\begin{array}{c}\text { Strongly } \\
\text { Agree }\end{array}$ \\
\hline & & $\%$ & $\%$ & $\%$ & $\%$ & $\%$ \\
\hline 1. & Palliative care improves quality life of patients & 4 & 4 & 11 & 54 & 27 \\
\hline 2. & $\begin{array}{l}\text { The palliative care should be started at the initial } \\
\text { stage }\end{array}$ & 2 & 20 & 17 & 40 & 21 \\
\hline 3. & $\begin{array}{l}\text { Nurse should establish a supportive relationship } \\
\text { with specialist palliative care providers }\end{array}$ & 4 & 2 & 16 & 53 & 25 \\
\hline 4. & $\begin{array}{c}\text { The advance directives are the right of the health } \\
\text { care professionals when patient is at end of life } \\
\text { stage }\end{array}$ & 4 & 12 & 51 & 26 & 7 \\
\hline
\end{tabular}




\begin{tabular}{|c|c|c|c|c|c|c|}
\hline 5. & $\begin{array}{l}\text { Nurse should only work in collaboration with client } \\
\text { for decision making }\end{array}$ & 5 & 25 & 17 & 43 & 10 \\
\hline 6. & $\begin{array}{c}\text { Nurse offers a support system to help patients live } \\
\text { as actively as possible until death }\end{array}$ & 1 & 4 & 13 & 51 & 31 \\
\hline 7. & $\begin{array}{l}\text { Palliative care doesn't help to relieve stressful } \\
\text { symptoms of the patients }\end{array}$ & 14 & 55 & 16 & 13 & 2 \\
\hline 8. & $\begin{array}{l}\text { The nurse's attitude towards the relatives should } \\
\text { be sympathetic }\end{array}$ & 1 & 10 & 19 & 50 & 20 \\
\hline 9. & $\begin{array}{l}\text { Nurse be willing to learn about the cultures of } \\
\text { their patients }\end{array}$ & 2 & 16 & 17 & 53 & 12 \\
\hline 10. & $\begin{array}{c}\text { A cultural assessment not guides individualized } \\
\text { care planning }\end{array}$ & 2 & 35 & 36 & 22 & 5 \\
\hline 11. & $\begin{array}{l}\text { Strong sense of spirituality or religious faith can } \\
\text { have a negative impact on health }\end{array}$ & 6 & 34 & 31 & 23 & 6 \\
\hline 12. & $\begin{array}{c}\text { Nurses can't alleviate distress and suffering and } \\
\text { enhance wellness by meeting their patients' } \\
\text { spiritual needs }\end{array}$ & 4 & 30 & 36 & 25 & 5 \\
\hline 13. & $\begin{array}{l}\text { Hearing emotional and spiritual concerns at the } \\
\text { end of life care gives peace to the patient }\end{array}$ & 19 & 59 & 14 & 2 & 6 \\
\hline 14. & $\begin{array}{l}\text { Good communication helps to improve end of life } \\
\text { care \& bereavement experience of patient's family }\end{array}$ & 4 & 4 & 13 & 50 & 29 \\
\hline 15. & $\begin{array}{l}\text { Good communication requires that you take time } \\
\text { to listen and answer patient's questions honestly }\end{array}$ & 4 & 2 & 9 & 46 & 39 \\
\hline 16. & $\begin{array}{l}\text { Respect the patients' right to health in any } \\
\text { condition }\end{array}$ & 0 & 3 & 6 & 52 & 39 \\
\hline 17. & $\begin{array}{l}\text { The Health professionals must have standards of } \\
\text { education, skill, and ethical codes of conduct }\end{array}$ & 1 & 4 & 11 & 47 & 37 \\
\hline 18. & $\begin{array}{l}\text { The patient doesn't feel intimidated during his/ her } \\
\text { first encounter with a legal person }\end{array}$ & 3 & 11 & 48 & 28 & 10 \\
\hline 19. & $\begin{array}{l}\text { The legal advice is not required for any disputes } \\
\text { after the death of a patient }\end{array}$ & 8 & 29 & 38 & 22 & 3 \\
\hline 20. & $\begin{array}{l}\text { Nurse experiences sense of failure and } \\
\text { hopelessness when patient dies }\end{array}$ & 7 & 25 & 36 & 26 & 6 \\
\hline
\end{tabular}

Whereas more than half of the student nurses disagreed much more in the questions related to (55\%) palliative care doesn't helps to relieve stressful symptoms of the patients; (59\%) hearing emotional and spiritual concerns at the end of life care gives peace to the patient.
Table 4, showed that the most respondents' attitudes levels towards palliative care were good attitude 58 (58\%), moderate attitude $42(42 \%)$, and no one had poor attitude level.

Table 4.Assessment of the nurses' attitude of palliative care

$(n=100)$

\begin{tabular}{|c|c|c|c|}
\hline Attitude level & Possible Range of Scores & Frequency & Percentage \\
\hline Poor attitude & $1-33$ & Nil & Nil \\
\hline Moderate attitude & $34-67$ & 42 & $42 \%$ \\
\hline Good attitude & $68-100$ & 58 & $58 \%$ \\
\hline
\end{tabular}


Table 5.Association of knowledge score with their selected demographic variables

\begin{tabular}{|c|c|c|c|c|c|c|}
\hline \multirow[b]{2}{*}{ Demographic Variable } & \multicolumn{2}{|c|}{ Percentage of obtained knowledge scores } & \multirow{2}{*}{$\begin{array}{c}\text { Chi } \\
\text { square }\end{array}$} & \multirow[b]{2}{*}{ D.f } & \multirow{2}{*}{$\begin{array}{l}\text { Table } \\
\text { value }\end{array}$} & \multirow[b]{2}{*}{ Inference } \\
\hline & $\begin{array}{c}\text { Inadequate } \\
\text { knowledge }(0-18)\end{array}$ & $\begin{array}{c}\text { Adequate knowledge } \\
(19-30)\end{array}$ & & & & \\
\hline \multicolumn{7}{|l|}{ Age } \\
\hline $18-19$ & 8 & 9 & \multirow{3}{*}{0.48} & \multirow{3}{*}{2} & \multirow{3}{*}{5.99} & \multirow{3}{*}{ NS } \\
\hline $20-21$ & 31 & 26 & & & & \\
\hline$>21$ & 15 & 11 & & & & \\
\hline \multicolumn{7}{|l|}{ Gender } \\
\hline Male & 44 & 37 & \multirow{2}{*}{0.22} & \multirow{2}{*}{1} & \multirow{2}{*}{3.84} & \multirow{2}{*}{ NS } \\
\hline Female & 10 & 9 & & & & \\
\hline \multicolumn{7}{|l|}{ Nursing course } \\
\hline DGNM $2^{\text {nd }}$ year & 24 & 11 & \multirow{3}{*}{6.62} & \multirow{3}{*}{2} & \multirow{3}{*}{5.99} & \multirow{3}{*}{$\mathrm{S}$} \\
\hline B.Sc. 3rd year & 19 & 16 & & & & \\
\hline B.Sc. 4th year & 11 & 19 & & & & \\
\hline \multicolumn{7}{|l|}{ Area of residence } \\
\hline Urban & 17 & 3 & \multirow[b]{2}{*}{9.67} & \multirow[b]{2}{*}{1} & \multirow[b]{2}{*}{3.84} & \multirow{2}{*}{$S$} \\
\hline Rural & 37 & 47 & & & & \\
\hline \multicolumn{7}{|l|}{ Religion } \\
\hline Hindu & 20 & 14 & \multirow{4}{*}{9.50} & \multirow{4}{*}{3} & \multirow{4}{*}{7.82} & \\
\hline Muslim & 29 & 28 & & & & $c$ \\
\hline Christian & - & 4 & & & & $\mathrm{~s}$ \\
\hline Others (Buddhism, Sikh) & 5 & - & & & & \\
\hline Previous knowledge & 54 & 46 & 0 & 1 & 3.84 & NS \\
\hline Previous experience & & & & & & \\
\hline Yes & 20 & 13 & O 87 & 1 & 381 & $N S$ \\
\hline No & 34 & 33 & 0.81 & $\perp$ & 3.84 & IVS \\
\hline Source of information & & & & & & \\
\hline Books & 15 & 12 & & & & \\
\hline Internet & 7 & 8 & & & & \\
\hline Friends and colleagues & 3 & 4 & O & 5 & 110 & NS \\
\hline Teacher & 22 & 19 & 0.10 & J & II.0 & ST \\
\hline Hospital & 6 & 3 & & & & \\
\hline Training or conferences & 1 & 0 & & & & \\
\hline
\end{tabular}

Table value of $\chi 2$ at $5 \%$ level, NS=Not significant, $S=$ Significant.

Table 5, indicates that there was significant association between the knowledge score and with nursing course, area of residence and religion as selected sociodemographic variables.

\section{Discussion}

In the present study which was conducted on Knowledge and Attitude regarding Palliative Care among Students Nurses in Selected College of Nursing, New Delhi. The results showed that 46 (46\%) of the Student Nurses had Adequate knowledge score whereas (54\%) of them had Inadequate knowledge score regarding Palliative Care. Most of the Student Nurses had (58\%) good attitude level regarding Palliative Care. 
In a similar study conducted by Aboshaiqah, Ahmad E, on Predictors of Palliative Care Knowledge among Nursing Students, Saudi Arabia. The result showed that the mean score obtained was 5.23 indicating poor palliative care knowledge. This study concludes that formulating education policies and interventions to enhance palliative care education and clinical training and ensure the quality of palliative care not only in Saudi Arabia but also in other countries. 8 The findings from a study conducted by Elsaman Suad Elsayed, on Knowledge and Attitudes Toward Caring Of Dying Patients, among Undergraduate Critical Care Nursing Students, Alexandria, Egypt. The result showed that the majority (82.61\%) had fair total attitude score and most of Nursing Students (76.1\%) had poor knowledge level toward dying patients. This study concludes that merging of critical care nursing course with Palliative Care education is needed. ${ }^{9}$

\section{Conclusion}

The present study concludes that most of the student nurses had inadequate knowledge regarding palliative care but many of the student nurses showed good attitude level regarding palliative care. The lack of knowledge and experience as well as professional limitations may have contributed to insufficient knowledge about palliative care in this study. A continuing palliative care education should be included to the nursing curriculum in order to attain a better palliative and effective quality care starting from the time of diagnosis. The administrators or nurse educator should encourage the student nurses or the registered nurses to conduct research related to assessment of knowledge and attitude regarding palliative care among student nurses. Thus, it's the responsibility of each individual of nursing profession to provide the utmost care to the patient, not at the end of life but at the initial stages of diagnosis of any disease whether it may be chronic or any terminal illness so as to provide a hope for the patient to live a peaceful life until death.

\section{Conflict of Interest: None}

\section{References}

1. World Health Organization. Definition of Palliative Care. Available from: palliative.stanford.edu soverview-ofpalliative-care.

2. Buss Mary K, Rock Laura K, McCarthy Ellen P et al. Understanding palliative care and hospice a review for primary care providers. Concise Review for Clinicians 2017; 92(2): 280-286.

3. Cruz ODM. Palliative care: an update. Missouri medicine. The Journal of the Missouri State Medical Association - Since 1904 2017; 114(2): 110-5.

4. Khosla D, Patel FD, Sharma SC. Palliative Care in India: current progress and future needs. Indian Journal of
Palliative Care 2012; 18(3): 149-154.

5. Sinha S, Sowmya G. No end to care - palliative care in India. Public Health Care System. Piramal Swasthya. 2020. Available from: https://www.piramalswasthya. org/no-end-to-care-palliative-care-in-india/.

6. Loscalzo Matthew J. Palliative care: An historical perspective. Pain management and supportive care for patients with haematological disorders. 2008; 1: 465.

7. Jennifer R. What diseases can be treated with palliative care? WebMD. 2019. Available from: https://www. webmd.com/palliative-care/when-is-palliative-careappropriate\#: :text=Today\%2C\%20patients $\% 20$ with\%20cancer\%2C\%20heart,primary\%20goals\%20 is\%20symptom\%20management.

8. Aboshaiqah, Ahmad E. Predictors of palliative care knowledge among nursing students in Saudi Arabia: a cross-sectional study. The Journal of Nursing Research 2020; 28(1): 60.

9. Elsayed ES. Undergraduate critical care nursing students' knowledge and attitudes toward caring of dying patients. Journal of Nursing and Health Science 2017; 6(1): 31. 